\title{
FLOOD-TOLERANCE RANKING OF RED AND FREEMAN MAPLE CULTIVARS
}

\author{
by Louis B. Anella' and Thomas H. Whitlow ${ }^{2}$
}

\begin{abstract}
Red maple (Acer rubrum) is often recommended for use in wet soils, yet its extensive native range suggests there may be genetic variation for traits associated with flood tolerance. Likewise, genetic variation for flood tolerance may be captured within red maple cultivars making some more appropriate than others for use in wet or low oxygen soils. Seven red maple cultivars (2-year-old trees)_'Autumn Flame ${ }^{(\circledR)}$ 'Bowhall', 'Karpick', 'Northwood', 'October Glory' ${ }^{\circledR}$, Red Sunset®, and 'Schlesinger- and 4 Freeman maple $(A . \times$ freemanii) cultivars-'Armstrong', 'Autumn Blaze', 'Morgan', and Scarlet Sentinel ${ }^{\mathrm{TM}}$, were ranked for flood tolerance by flooding the trees and characterizing photosynthesis, lenticel intumescence, and survival. Indicator trees representing the wet extreme of red maple's native range were also included for comparison. Net photosynthesis declined for all cultivars; however, 'Schlesinger', Red Sunset and 'Bowhall' had the highest net photosynthetic rates (ranging from 1.94 to $1.71 \mu \mathrm{mol} / \mathrm{m}^{2} \mathrm{~s}$ ) after 45 days of flooding. In contrast, 'Karpick', 'Autumn Flame', and 'Northwood' had net photosynthetic rates near 0 . The extent of lenticel intumescence also varied among the cultivars with 'Schlesinger' and 'Bowhall' producing the longest lenticels. All of the 'Northwood' trees died, as did two-thirds of the 'Autumn Flame' trees. The cultivars were separated into 3 overall flood-tolerance rankings: high ('Schlesinger', Red Sunset, and 'Bowhall'), intermediate ('Armstrong', 'Morgan', 'October Glory', Scarlet Sentinel, and 'Autumn Blaze'), and low ('Karpick', 'Autumn Flame', and 'Northwood').
\end{abstract}

Key Words. Genetic variation; lenticel intumescence; photosynthesis; red maple (Acer rubrum L.); Freeman maple $(A, \times$ freemanii E. Murray).

Red maple has perhaps the greatest geographic range of any tree in eastern North America (Walters and Yawney 1990) but even more impressive is its ability to thrive at the extremes of soil moisture availability. Despite its prevalence on wet and dry sites, red maple is often characterized as a flood-tolerant species suitable for planting in moist soils (Dirr 1990; van Gelderen et al. 1994) and it is one of the most commonly planted landscape trees (Kielbaso 1990) with 48 recognized cultivars (Santamour and McArdle 1982).
The broad geographic and edaphic range of red maple suggests that either the species is able to acclimate to many different environmental conditions or it possesses a high degree of genetic variation. Using seedlings from throughout red maple's geographic range, Townsend (1983) reported variation for growth rate, fall color, cold hardiness, drought tolerance, ozone exposure, deicing salts, and Verticillium wilt. In contrast, Abrams and Kubiske (1990) compared the drought tolerance of red maple seedlings from wet and dry sites and suggested that genotypic variation accounted for only part of red maple's broad range and that plasticity played an important role. Testing red maple seedlings for flood tolerance, Will et al. (1995) reported no interaction between flooding treatment and maternal hydrologic conditions, while Anella (1994) reported that 1-year-old flooded wet-site seedlings maintained higher photosynthetic rates, produced larger hypertrophied lenticels, had more adventitious roots, and suffered less mortality than flooded dry-site seedlings.

Recognizing that red maple is recommended for planting in wet soils, we wondered if all red maple cultivars are flood tolerant or if some cultivars are better suited for wet soil than others. Has some of the purported genetic variation for flood tolerance been captured within the cultivars? Cultivar evaluation for abiotic stress tolerance is not common but could prove valuable for species with a high degree of genetic variation (Townsend 1983). We do not know of any studies that rank red maple cultivars for flood tolerance; however, studies evaluating ozone tolerance (Findley et al. 1996) and high root temperature tolerance (Wilkins et al. 1995) have been conducted. The later study concluded that there was enough genetic variation among red maple cultivars to recommend some over others for use in soils with elevated temperatures.

Flood-tolerant species have been recommended for use in urban settings because of their ability to produce new, shallow root systems-an adaptation that may aid root growth in compacted urban soils 
(Perry 1982). Therefore, a ranking of cultivar flood tolerance might also be used to suggest which cultivars are best for planting in urban sites.

We evaluated 11 cultivars, 7 red maple and 4 red and silver maple hybrids ( $A . \times$ freemanii), for flood tolerance by flooding the trees and measuring photosynthesis, lenticel intumescence, and survival.

\section{MATERIALS AND METHODS}

The following red maple cultivars were donated by J. Frank Schmidt and Son Inc. (Boring, Oregon): 'Armstrong', 'Autumn Blaze', 'Autumn Flame' ${ }^{\circledR}$, 'Bowhall', 'Karpick', 'Morgan', 'Northwood', 'October Glory' ${ }^{\circledR}$, 'Franksred' (Red Sunset $\left.{ }^{\circledR}\right)$, 'Scarsen' (Scarlet Sentinel ${ }^{\mathrm{TM}}$ ), and 'Schlesingeri' (Schlesinger). These are all listed as Acer rubrum in the Schmidt catalog; however, Dirr (1990) classifies the following cultivars as $A$. $\times$ freemanii (an $A$. rubrum $\times A$. saccharinum hybrid): 'Armstrong', 'Autumn Blaze', 'Morgan', and Scarlet Sentinel, while Santamour and McArdle (1982) refer to only 'Autumn Blaze' as a hybrid. All 11 cultivars were studied and ranked without regard to their hybrid or nonhybrid classification. Two-year-old dormant liners were shipped bare root to Ithaca, New York, where they were received on March 29, 1995. They were promptly planted in 11.3-L ( 3 gal) plastic pots with a greenhouse soil mix ( 1 part loam, 2 parts peat moss, and 1 part perlite) and were maintained outdoors as a containerized nursery crop for 13 weeks until the flooding treatment was imposed.

For each cultivar and the l-year-old trees grown from seed collected along the James River in Chesterfield County, Virginia, 6 trees were selected for uniform size then flooded as explained below. Three of the 6 trees were randomly selected for gas exchange measurements. The James River trees (JR) represent the wet extreme of red maple's hydrologic range and therefore were used as indicator trees in this study representing a flood-tolerant population but were not included in statistical comparisons. Henceforth, we will loosely refer to all trees used in this study as "cultivars" for the sake of simplicity, recognizing that the JR trees are neither cultivars nor clonal.

The trees, fully leafed-out, were flooded by placing the potted plants in 23-L (6 gal) buckets filled with tapwater and irrigated daily to maintain a water level 8 to $10 \mathrm{~cm}$ ( 3 to 4 in.) above the soil surface.
Trees were randomly placed $1 \mathrm{~m}(3 \mathrm{ft})$ apart in rows on a gravel pad in full sun. To facilitate making all gas exchange measurements between 10 A.M. and noon, trees were divided into 2 blocks with 6 cultivars in each block; however, by the experiment's end enough trees had died that all photosynthetic measurements could be taken in 1 day within the 2-hour time frame, so blocking became unnecessary because only the last photosynthetic measurement was used to rank the cultivars.

Gas exchange was measured using a LI 6200 Portable Photosynthesis System (LI-COR, Lincoln, Nebraska) on day 0 before flooding the trees and thereafter on days $3,9,17,28,38$, and 46 and days $2,8,16,27,37$, and 44 for blocks 1 and 2 , respectively. All measurements were taken with natural light at a minimum of $1,200 \mu \mathrm{mol} / \mathrm{m}^{2} \mathrm{~s}$. The results represent the mean of 3 replicate trees per cultivar and 3 leaves per tree.

Flooding commenced on July 10, 1995, for block 1 and on July 12, 1995, for block 2. All trees were approximately $1 \mathrm{~m}(3 \mathrm{ft}$ ) tall except for the JR trees, which were approximately $1.25 \mathrm{~m}(4 \mathrm{ft})$ tall.

Gas exchange measurements, lenticel intumescence, and survival were recorded and used to rank the cultivars for flood tolerance. Each parameter was scaled between 0 and 1 , with 0 representing low flood tolerance and 1 representing greater flood tolerance, by assigning a value of 1 to the highest recorded measurement and a value of 0 for the lowest recorded measurement with all other measurements appropriately scaled in between. Trees that died during the experiment were assigned a rank of 0 , while those that lived were assigned a rank of 1 .

The extent of lenticel intumescence was estimated by observing the flooded portion of the stem at the end of the experiment. The trees were ranked from 0 to 1 based on the average length of the hypertrophied lenticels as follows: $0=<1 \mathrm{~mm}, 0.25=1$ to $3 \mathrm{~mm}$, $0.50=3$ to $6 \mathrm{~mm}, 0.75=6$ to $9 \mathrm{~mm}$, and $\mathrm{l}=>9 \mathrm{~mm}$.

A weighted average of the 3 parameters was used to obtain an overall ranking for flood tolerance. Survival and lenticel intumescence were assigned a weight of 1 and gas exchange was assigned a weight of 3. Gas exchange was assigned a higher weight because it is a continuous variable that has been used in other studies to rank species for flood tolerance (Kozlowski 1984). 
Means for each parameter and the weighted average were analyzed using Hsu's multiple comparisons test (Minitab; State College, Pennsylvania). This test provides confidence intervals for the difference between each level mean and the best of the other level means with 2 choices for best: largest is best or smallest is best. Using each of these tests resulted in 3 flood-tolerance rankings: high, intermediate, and low. Choosing "largest is best" identified cultivars with means significantly lower than the best, and these cultivars were assigned the low flood-tolerance ranking. Choosing "smallest is best" identified cultivars with means significantly higher than the best, and these cultivars were assigned the high flood-tolerance ranking. Cultivars that were not significantly different from the best in either of the tests were assigned the intermediate flood-tolerance ranking.

\section{RESULTS AND DISCUSSION}

On day 0 , before the trees were flooded, gas exchange rates ranged from 13.25 to $9.64 \mu \mathrm{mol} / \mathrm{m}^{2} \mathrm{~s}$ (Figure 1). These rates span a range similar to those measured by Sibley et al. (1996), who used mostly the same red maple cultivars for a study of growth and photosynthesis in Alabama. In their study, initial gas exchange rates ranged from a high of $14.4 \mu \mathrm{mol} / \mathrm{m}^{2} \mathrm{~s}$ to a low of $8.5 \mu \mathrm{mol} / \mathrm{m}^{2} \mathrm{~s}$.

Once the trees were flooded, photosynthesis declined rapidly, as has been found with many other flooding experiments (see reviews by Sojka and Stolzy 1980; Hook 1984; Kozlowski 1984; Ernst 1990). By day 9 , photosynthetic rates had fallen to less than half their pre-flood value and by day 24 (midway through the experiment), most of the cultivars had reached their lowest photosynthetic rates and did not change considerably for the remainder of the experiment.

Survival in flooded soils depends partly on the plant's ability to maintain net positive $\mathrm{CO}_{2}$ fixation (Pezeshki and Chambers 1986), and many studies have shown that the more flood-tolerant species or ecotype maintains or recovers to a higher photosynthetic rate than an intolerant species or ecotype (Pezeshki and Chambers 1986; Osonubi and Osundina 1987; Pezeshki et al. 1996). Therefore, the final net photosynthetic rate was used to rank the cultivars in this study for flood tolerance.

Schlesinger (1.94 $\left.\mu \mathrm{mol} / \mathrm{m}^{2} \mathrm{~s}\right)$, Red Sunset ( 1.76 $\mu \mathrm{mol} / \mathrm{m}^{2} \mathrm{~s}$ ), and 'Bowhall' (1.71 $\mu \mathrm{mol} / \mathrm{m}^{2} \mathrm{~s}$ ) had sig-

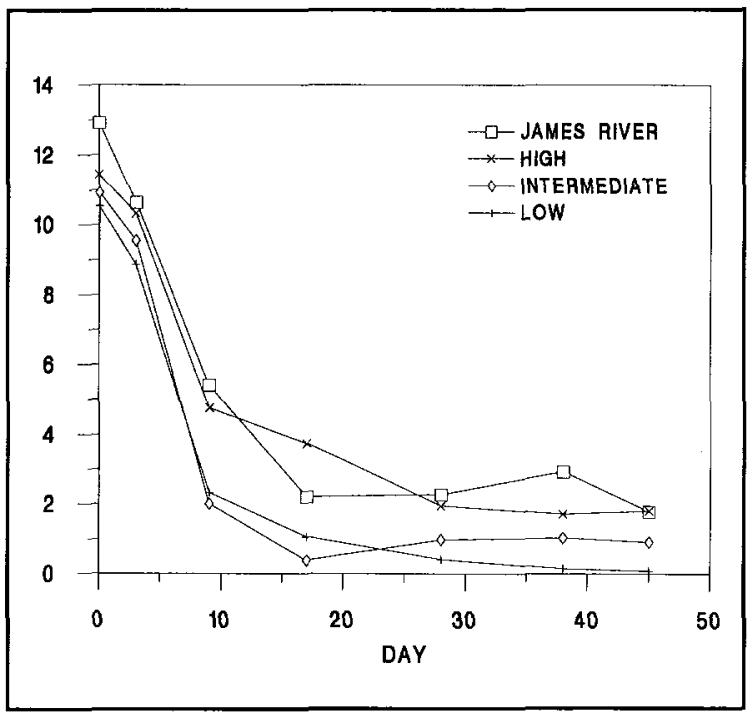

Figure 1. Net photosynthesis of flooded red and Freeman maple cultivars. Trees were flooded on day 0 , after gas exchange measurements were taken, and remained flooded for 45 days. James River trees were included in the study as an indicator of flood tolerance but were not included in the statistical analysis. Results are presented as the average for high (significantly greater than intermediate or low at $\boldsymbol{P}=\mathbf{0 . 0 5}$ ), intermediate, and low (significantly less than high or intermediate at $P=0.10$ ) flood tolerance rankings. High $=$ Schlesinger, Red Sunset, and 'Bowhall'; Intermediate = 'Armstrong', 'Morgan', 'October Glory', Scarlet Sentinel, and 'Autumn Blaze'; Low = 'Karpick', 'Autumn Flame', and 'Northwood'.

nificantly higher final average gas exchange rates, while those ranked as intermediate for gas exchange ranged from 1.45 to $0.43 \mu \mathrm{mol} / \mathrm{m}^{2} \mathrm{~s}$ (Table 1 ). 'Karpick' (0.21 $\left.\mu \mathrm{mol} / \mathrm{m}^{2} \mathrm{~s}\right)$, 'Autumn Flame' (0.02 $\left.\mu \mathrm{mol} / \mathrm{m}^{2} \mathrm{~s}\right)$, and 'Northwood' $\left(0.00 \mu \mathrm{mol} / \mathrm{m}^{2} \mathrm{~s}\right)$ had the lowest rates. The JR trees that were used as indicators of flood tolerance had a final rate of 1.77 $\mu \mathrm{mol} / \mathrm{m}^{2} \mathrm{~s}$, similar to the rates measured for Schlesinger, Red Sunset, and 'Bowhall'. It is interesting to note that Schlesinger, which had the highest final gas exchange rate, had the second lowest preflood rate.

The ability of roots to survive and function when inundated is an important adaptation to flooding stress. One possible morphological mechanism of flood tolerance is the production of 
adventitious roots that grow near the water's surface or at the soil-water interface-both zones of comparatively higher oxygen content (Ponnamperuma 1972; Armstrong 1975; Gill 1975). Sena Gomes and Kozlowski (1980) suggest that the reopening of stomata coincides with the production of adventitious roots, leading to a rise in photosynthesis. In the present study, there was no appreciable recovery of lost photosynthetic potential by any of the cultivars. Likewise, there was no appreciable production of adventitious roots. By the experiment's end, only 2 'Autumn Flame' trees and 1 each of Schlesinger and the James River trees had produced a few small adventitious roots. In previous studies, we observed extensive adventitious root development on the JR trees. It is unclear why we observed so little adventitious root development but it precluded the use of this character as an indicator of flood tolerance for this study.

Another important adaptation to flooded conditions is the transfer of oxygen to the roots through what is most likely a diffusive pathway through intercellular spaces inside the stem (Armstrong 1968). Hook et al. (1970) reported that oxygen enters the stem through lenticels that swell in response to flooding, providing oxygen for respiration (Armstrong
1975). Species intolerant of flooding often do not display this morphological response. Instead, their lenticels remain small and surrounded by a closing layer limiting gaseous diffusion (Osonubi and Osundina 1987; Terazawa and Kikuzawa 1994). Topa and McLeod (1986) reported greater rhizosphere oxidation and lenticel intumescence for flood-tolerant pond pine (Pinus serotina) and wet-site loblolly pine ( $P$. taeda) than for less tolerant dry-site loblolly pine and sand pine ( $P$. clausa). They found abundant intercellular spaces in the pericycle region adjacent to lenticels of flooded wet-site loblolly pine seedlings, yet intercellular air spaces were mostly absent in flooded drysite loblolly seedlings. In our previous studies, we have noticed that the more tolerant wet-site red maple seedlings produce long ( $>1 \mathrm{~cm}[0.4 \mathrm{in}$.]) columns of cells in response to flooding that are extremely brittle and slough off when touched, while dry-site seedlings show little or no lenticel intumescence (Anella 1994).

Although not included in the statistical comparisons, JR trees had the highest average lenticel rating (0.75). Among the commercial cultivars, Schlesinger and 'Bowhall' had significantly higher ratings (0.58 and 0.67 , respectively) than the other cultivars, while 'Morgan', Scarlet Sentinel, 'Autumn Blaze', and 'Karpick' had significantly lower ratings (Table 1).

Table 1. The overall flood tolerance ranking is based on the weighted average comprised of the net photosynthetic rate (A) after $\mathbf{4 5}$ days of flooding, lenticel rating, and the percent survival. Values for the indicator $J R$ trees are also presented but are not included in statistical comparisons.

\begin{tabular}{llllll}
\hline \multirow{2}{*}{ Overall ranking } & Cultivar & Weighted average & $\begin{array}{l}\text { Day } 45, \mathrm{~A} \\
\left(\mu \mathrm{mol} / \mathrm{m}^{2} \mathrm{~s}\right)\end{array}$ & Lenticel rating & Survival (\%) \\
\hline \multirow{4}{*}{ High } & James River & & 1.77 & 0.75 & 100 \\
& Schlesinger & $.68 \mathrm{H}$ & $1.94 \mathrm{H}$ & $0.58 \mathrm{H}$ & 100 \\
& Red Sunset & $.62 \mathrm{H}$ & $1.76 \mathrm{H}$ & $0.42 \mathrm{I}$ & 100 \\
Intermediate & 'Bowhall' & $.59 \mathrm{H}$ & $1.71 \mathrm{H}$ & $0.67 \mathrm{H}$ & 67 \\
& 'Armstrong'* & $.49 \mathrm{I}$ & $1.09 \mathrm{I}$ & $0.42 \mathrm{I}$ & 100 \\
& 'Morgan'* & $.46 \mathrm{I}$ & $1.45 \mathrm{I}$ & $0.25 \mathrm{~L}$ & 67 \\
& 'October Glory' & $.38 \mathrm{I}$ & $0.94 \mathrm{I}$ & $0.33 \mathrm{I}$ & 67 \\
& Scarlet Sentinel* & $.37 \mathrm{I}$ & $0.66 \mathrm{I}$ & $0.25 \mathrm{~L}$ & 100 \\
& 'Autumn Blaze'* & $.33 \mathrm{I}$ & $0.43 \mathrm{I}$ & $0.25 \mathrm{~L}$ & 100 \\
& 'Karpick' & $.21 \mathrm{~L}$ & $0.21 \mathrm{~L}$ & $0.17 \mathrm{~L}$ & 67 \\
& 'Autumn Flame' & $.20 \mathrm{~L}$ & $0.02 \mathrm{~L}$ & $0.33 \mathrm{I}$ & 33 \\
& 'Northwood' & $.07 \mathrm{~L}$ & $0.00 \mathrm{~L}$ & $0.25 \mathrm{I}$ & 0 \\
\hline
\end{tabular}

\section{*A. $\times$ freemanii.}

$\mathrm{H}=$ High flood tolerance; significantly greater than 1 or $\mathrm{L}$ at $P=0.05$ using Hsu's multiple comparison test. "smallest is best."

$\mathrm{I}=$ Intermediate flood tolerance; those means that were not identified as the best using "largest is best" or "smallest is best" tests.

$\mathrm{L}=$ Low flood tolerance; significantly less than $\mathrm{H}$ or I at $P=0.10$ using Hsu's multiple comparison test "largest is best." 
'Northwood' was the only cultivar for which all 3 replicates suffered complete mortality, and it was the first cultivar to display this symptom of flooding stress. Two out of 3 'Autumn Flame' trees suffered foliar desiccation, as did 1 tree of each of the following cultivars: 'Bowhall', 'Karpick', 'Morgan', and 'October Glory'. All trees of the remaining 5 cultivars survived throughout the experiment, as did the JR trees.

Schlesinger, Red Sunset, and 'Bowhall' had significantly higher $(P=0.05)$ weighted averages than the other cultivars, indicating a higher level of flood tolerance. In contrast, 'Karpick', 'Autumn Flame', and 'Northwood' had significantly lower $(P=0.10)$ weighted averages, indicating a low level of flood tolerance. The $4 A, \times$ freemanii hybrid cultivars and 'October Glory' were ranked as intermediate.

A few other recent studies have compared the performance of red maple cultivars. Sibley et al. (1995) used fall color, height, and diameter growth as criteria to evaluate red maple cultivars for use in the southeastern United States. Superior cultivars were 'Autumn Flame', 'Autumn Blaze', Fairview Flame, and 'October Glory', while 'Northwood' and 'Karpick' were found to be poor selections for this region. In a study comparing the growth of 'October Glory' and 'Northwood' trees in styrene-lined and copper-coated containers, Brass et al. (1996) reported that 'October Glory' had a higher growth rate and higher root dry weight than did 'Northwood', regardless of treatment. Wilkins et al. (1995) studied the tolerance of red and Freeman maples to high root-zone temperature and found Red Sunset and 'Indian Summer' to be relatively sensitive, while 'Autumn Flame', 'Jeffersred', and Schlesinger were relatively resistant to high root-zone temperature.

\section{CONCLUSIONS}

JR trees were included in the study as an indicator of flood tolerance, and the similarities between the results obtained for JR trees and the trees assigned the high flood-tolerance ranking suggests that these cultivars possess some of the adaptations important for flood tolerance. The statistically significant differences found among the cultivars support the hypothesis that there exists genetic variation within red maple for the characteristics associated with flood tolerance and that some of that variation has been captured among the cultivars included in this study.
The results reported in our flooding study indicate a high degree of genetic variability among red maple cultivars and support the assertion that cultivar evaluations are necessary to direct the use of appropriate cultivars in stressful sites. The results of this study indicate that Schlesinger, Red Sunset, and 'Bowhall' are appropriate for planting in wet soils, while the use of 'Karpick', 'Autumn Flame', and 'Northwood' should be avoided in wet soils. The similarities between the 3 high flood-tolerant cultivars and the JR trees suggest that selecting new cultivars for flood tolerance may not be necessary because the appropriate traits already exist in commonly available cultivars.

\section{LITERATURE CITED}

Abrams, M.D., and M.E. Kubiske. 1990. Photosynthesis and water relations during drought in Acer rubrum L. genotypes from contrasting sites in central Pennsylvania. Func. Ecol. 4:727-733.

Anella, L.B. 1994. Photosynthesis during flooding of Acer rubrum L. populations from contrasting habitats. M.S. thesis. Cornell University, Ithaca, New York.

Armstrong, W. 1968. Oxygen diffusion from the roots of woody species. Physiol. Plant. 21:539-543.

Armstrong, W. 1975. Waterlogged soils, pp 181-218. In Etherington, J.R. (Ed.). Environment and Plant Ecology. Wiley and Sons, New York, NY

Brass, T.J., G.J. Keever, J.D. Eakes, and C.H. Gilliam. 1996. Styrene-lined and copper-coated containers affect production and landscape establishment of red maple. HortScience 31:353-356.

Dirr, M.A. 1990. Manual of Woody Landscape Plants: Their Identification, Ornamental Characteristics, Culture, Propagation and Uses. Stipes Publishing, Champaign, IL.

Ernst, W.H.O. 1990. Ecophysiology of plants in waterlogged and flooded environments. Aquatic Bot. 38:73-90.

Findley, D.A., G.J. Keever, A.H. Chappelka, D.J. Eakes, and C.H. Gilliam. 1996. Sensitivity of red maple cultivars to acute and chronic exposures of ozone. J. Arboric. 22:264-269.

Gill, C.J. 1975. The ecological significance of adventitious rooting as a response to flooding in woody species, with special reference to Alnus glutinosa (L.) Gaertn. Flora, Bd. 164:85-97.

Hook, D.D. 1984. Adaptations to flooding with fresh water, pp 265-294. In Kozlowski, T.T. (Ed.).. Flooding and Plant Growth. Academic Press, New York, NY. 
Hook, D.D., C.L. Brown, and P.P. Kormanik. 1970. Lenticel and water root development of swamp tupelo under various flooding conditions. Bot. Gaz. $131: 217-224$.

Kielbaso, J.J. 1990. Trends and issues in city forests. J. Arboric. 16:69-76.

Kozlowski, T.T, 1984. Responses of woody plants to flooding, pp 129-163.In Kozlowski, T.T. (Ed.). Flooding and Plant Growth. Academic Press, New York, NY.

Osonubi, O., and M.A. Osundina, 1987. Stomatal responses of woody seedlings to flooding in relation to nutrient status in leaves. J. Exp. Bot. 38:1166-1173.

Perry, T.O. 1982. Trees roots-where they grow: Implications and practical significance. J. Arboric. 8:197-211.

Pezeshki, S.R., and J.L. Chambers. 1986. Variation in floodinduced stomatal and photosynthetic responses of three bottomland tree species. Forest Sci. 32:914-923.

Pezeshki, S.R., J.H. Pardue, and R.D. DeLaune. 1996. Leaf gas exchange and growth of flood-tolerant and floodsensitive tree species under low soil redox conditions. Tree Physiol. 16:453-458.

Ponnamperuma, F.N. 1972. The chemistry of submerged soils. Adv. Agron. 24:29-96

Santamour, F.S. Jr., and A.J. McArdle. 1982. Checklist of cultivated maples I. Acer nubrum L. J. Arboric. 8:110112.

Sena Gomes, A.R., and T.T. Kozlowski. 1980. Growth responses and adaptations of Fraximus pennsyluanica seedlings to flooding. Plant Physiol. 66:267-271.

Sibley, J.L., D.J. Eakes, C.H. Gilliam, G.J. Keever, and W.A. Dozier, Jr. 1995. Growth and fall color of red maple selections in the southeastern United States. J. Environ. Hortic. 13:51-53.

Sibley, J.L., D.J. Eakes, C.H. Gilliam, G.J. Keever, and W.A. Dozier, Jr. 1996. Gas exchange rates for selected red maple cultivars grown in Alabama. J. Environ. Hortic. 14:30-32.

Sojka, R.E., and L.H. Stolzy. 1980. Soil-oxygen effects on stomatal response. Soil Sci. 130:350-358.

Terazawa, K., and K. Kikuzawa. 1994. Effects of flooding on leaf dynamics and other seedling responses in floodtolerant Alnus japonica and flood-intolerant Betula platyphylla var. japonica. Tree Physiol. 14:251-261.
Topa, M.A., and K.W. McLeod. 1986. Responses of Pinus clausa, Pinus serotina and Pinus taeda seedlings to anaerobic solution culture. II. Changes in tissue nutrient concentration and net acquisition. Physiol. Plant. 68:532-539.

Townsend, A.M. 1983. Genetic potential of red maple for urban use. In Gerhold, H. (Ed.). Proceedings: The Fourth Conference of the Metropolitan Tree Improvement Alliance.New York Botanical Gardens, Bronx, NY. June 20-21, 1983.

van Gelderen, D.M., P.C. de Jong, and H.J. Oterdoom. 1994. Maples of the World. Timber Press, Portland, OR.

Walters, R.S., and H.W.Yawney. 1990. Acer rubrum L., red maple. In Silvics of North America. Agricultural Handbook 654 Vol. II, Hardwoods. USDA, Washington, DC.

Wilkins, L.C., W.R. Graves, and A.M. Townsend. 1995. Responses to high root-zone temperature among cultivars of red maple and Freeman maple. J. Environ. Hortic. 13:82-85.

Will, R.E., J.R.Seiler, P.P. Feret, and W.M. Aust. 1995. Effects of rhizosphere inundation of the growth and physiology of wet and dry-site Acer rubrum (red maple) populations. Am. Midl. Nat. 134:127-139.

Acknowledgements. We wish to thank Keith Warren and J. Frank Schmidt and Son Co. for the generous donation of trees used in this study and Nina L. Bassuk, Todd E. Dawson, and Timothy L. Setter for reviewing the manuscript.

1360 Agriculture Hall

Oklahoma State University

Stillwater, OK 74078

(405-744-6593)

${ }^{2} 20$ Plant Science

Cornell University

Ithaca, NY 14853 
Résumé. Lérable rouge (Acer rubrum) est régulièrement recommandé dans les sols humides bien que son habitat très vaste suggère qu'il pourrait y avoir des variations génétiques de caractère de tolérance à l'inondation. De même, la variation génétique de la tolérance à l'inondation peut être fixée dans les cultivars d'érables rouges afin de créer certaines sélections plus appropriées que d'autres pour les sols mouillés ou faibles en oxygène. Sept cultivars d'érables rouges âgés de deux ans-'Autumn Flame'(B), 'Bowhall', 'Karpick', 'Northwood', 'October Glory'(B), 'Red Sunset'(B) et 'Schlesinger'-et quatre cultivars d'érables de Freeman $(A . \times$ freemanii $)$ 'Armstrong,, 'Autumn Blaze', 'Morgan' et 'Scarlet Sentinel' ${ }^{\text {TM }}$ —ont été classés pour leur tolérance à l'inondation en les inondant pour en caractériser la photosynthèse, le gonflement des lenticelles et la survie. Des arbres indicateurs représentant l'habitat le plus humide observé pour l'érable rouge ont aussi été inclus à titre de comparaison. La photosynthèse nette a décliné chez tous les cultivars; par contre les cultivars 'Schlesinger', 'Red Sunset' et 'Bowhall' avaient les plus hauts taux de photosynthèse nette (entre 1,94 et $1,71 \mu \mathrm{mol} / \mathrm{m}^{2} \mathrm{~s}$ ) après 45 jours d'inondation. À l'opposé, les cultivars 'Karpick', 'Autumn Flame' et 'Northwood' avaient des taux de photosynthèse nette près de zéro. Le gonflement des lenticelles variait lui aussi entre les cultivars avec les plus longues lenticelles produites par 'Schlesinger' et 'Bowhall'. Les cultivars ont été classés selon trois gradients de tolérance à l'inondation: élevée-'Schlesinger', 'Red Sunset' et 'Bowhall'; moyenne - Armstrong', 'Morgan', 'October Glory', 'Scarlet Sentinel' et 'Autumn Blaze'; faible-_Karpick', 'Autumn Flame' et 'Northwood'.

Zusammenfassung. Rotahorn wird oft für nasse Böden empfohlen, obwohl seine extensive naturliche Bandbreite eher vorgibt, daß es hier möglicherweise genetische Variatione in Bezug auf Fluttoleranz gibt. Zum Beispiel: die genetische Variation für Fluttoleranz kann innerhalb der Rotahornkultivaren so abweichend sein, daß einige mehr als andere f" $r$ den Einsatz auf nassen oder sauerstoffarmen Böden geeignet sind. Sieben Rotahornkultivare (2 Jahre alt) Autumn Flame ${ }^{\circledR}$, Bowhall, Karpick, Northwood, October Glory ${ }^{\circledR}$, Red Sunset ${ }^{\circledR}$ und Schlesinger und vier Freeman Ahorne $(A . \times$ freemanii) Armstrong, Autumn Blaze, Morgan und Scarlet Sentinel ${ }^{\mathrm{TM}}$ wurden durch Überflutung der Pflanzen und anschließende Charakterisierung der Photosynthese, der Intumeszenz der Lentizellen und der Uberlebensrate in eine Reihenfolge gestellt. Zum Vergleich wurden Bäume, die das nasse Extrem der natürlichen Bandbreite repräsentieren, in die Studie miteinbezogen. Die Netto- photosynthese sank bei allen Kultivaren. Dennoch hatten Schesinger, Red Sunset und Bowhall nach 45 Tagen Uberflutung die höchste Photosyntheserate (reichend von 1.94 bis $1.71 \mu \mathrm{mol} / \mathrm{m}^{2} \mathrm{~s}$ ). Die Ausdehnung der Lentizellenintumeszenz variierte ebenso zwischen den Kultivaren, wobei Schlesinger und Bowhall die längsten Lentizellen produzierten. Alle Northwood-Exemplare starben, ebenso zwei Drittel aller Autumn FlameKultivare. Die Kultivare wurden bezüglich ihrer Fluttoleranz in drei Hauptgruppen getrennt mit folgender Reihenfolge: hoch-Schlesinger, Red Sunset und Bowhall; mittel-Armstrong, Morgan, October Glory, Scarlet Sentinel und Autumn Blaze; niedrig-Karpick, Autumn Flame und Northwood.

Resumen. El arce rojo (Acer rubrum) es con frecuencia recomendado para uso en suelos húmedos aunque su extenso rango nativo sugiere una posible variación genética para las características asociadas con la tolerancia a las inundaciones. Igualmente, la variación genética para la tolerancia a la inundación puede estar capturada dentro de los distintos cultivares de arce rojo haciendo algunos más apropiados que otros para uso en suelos húmedos o de baja concentración de oxígeno. Se clasificaron por su tolerancia a la inundación siete cultivares de arce rojo (árboles de dos a tres años de edad), 'Autumn Flame'®), 'Bowhall', 'Karpick', 'Northwood', 'October Glory' ${ }^{\circledR}$, Red Sunset ${ }^{\circledR}$, y 'Schlensinger', y 4 cultivares de arce Freeman (A. $\times$ freemanii), 'Ármstrong', 'Autumn Blaze', 'Morgan', y Scarlet Sentinel ${ }^{\mathrm{TM}}$, mediante la anegación de los árboles, caracterizando la fotosíntesis, la intumescencia de las lenticelas, y la supervivencia. También se incluyeron para la comparación, árboles indicadores que representaban los rangos nativos extremos para la humedad, en los arces rojos. La fotosíntesis neta descendió para todos los cultivares; sin embargo, 'Schlensinger', Red Sunset, y 'Bowhall' tuvieron las tasas más altas de fotosintesis neta (de 1.94 a $1.71 \mu \mathrm{mol} / \mathrm{m}^{2} \mathrm{~s}$ ) después de 45 días de inundación. En contraste, 'Karpick', 'Autumn Flame', y 'Northwood' tuvieron una fotosíntesis neta cercana a cero. La extensión de la intumescencia de las lenticelas también varió entre los cultivares con 'Schlensinger' y 'Bowhall' produciendo lenticelas más largas. Todos los árboles de 'Northwood' murieron, como también dos tercios de los de 'Autumn Flame'. Los cultivares estuvieron separados en tres rangos de tolerancia a la inundación: alta'Schlensinger', Red Sunset, y 'Bowhall'; intermedia'Armstrong', 'Morgan', 'October Glory', Scarlet Sentinel, y 'Autumn Blaze'; baja-'Karpick', 'Autumn Flame', y 'Northwood'. 